\title{
PEMBERIAN GAJI KEPADA PENGURUS YAYASAN BERDASARKAN UNDANG-UNDANG YAYASAN
}

\author{
Nira Hustiana dan Muhammad Ardi Pradana \\ Program Studi Magister Kenotariatan fakultas Hukum \\ Universitas Airlangga
}

\begin{abstract}
Abstrak
Yayasan merupakan badan hukum yang dilahirkan dengan pemisahan suatu harta kekayaan untuk tujuan tertentu dibidang sosial. Kekayaan yang telah menjadi milik yayasan tidak dapat dialihkan baik secara langsung maupun tidak langsung kepada organ yayasan, baik dalam bentuk gaji, upah atau honorarium. Undang-Undang Yayasan memberikan pengecualian kepada pengurus yayasan untuk dapat memperoleh gaji dari yayasan, tetapi dengan syarat-syarat yang telah ditetapkan oleh Undang-Undang Yayasan. Hal ini dimaksudkan karena pengurus yayasan mempunyai tanggung jawab yang besar mengenai kepengurusan yayasan. Atas dasar tanggung jawab tersebut, sehingga pengurus yayasan layak untuk mendapatkan gaji. Dalam praktik, pemenuhan syarat hanya dengan pengakuan belaka. Syarat-syarat tersebut yaitu dituangkan dalam anggaran dasar, ditetapkan oleh pembina, pengurus bukan pendiri dan tidak terafiliasi dengan pendiri, pembina dan pengawas dan melaksanakan kepengurusan secara langsung dan penuh. Penetapan dalam anggaran dasar adalah sebagai syarat paling utama agar syarat lainnya mempunyai dasar hukum. Untuk memastikan bahwa pengurus tidak terafiliasi dengan pendiri, pembina dan pengawas maka perlu dimintakan pembuktian berupa dokumen-dokumen, misalkan kartu keluarga masing-masing organ. Apabila anggaran dasar belum mencantumkan pengurus boleh menerima gaji, maka dilakukan perubahan anggaran dasar.
\end{abstract}

Kata Kunci: yayasan, pengurus yayasan, pemberian gaji

\section{GIVING SALARY TO THE FOUNDATION MANAGEMENT BASED ON THE FOUNDATION LAW}

\author{
Nira Hustiana and Muhammad Ardi Pradana \\ Master Program of Notary, Faculty of Law \\ Airlangga University
}

\begin{abstract}
Foundation is a legal entity containing the distribution of a property for a particular purpose in the social field. The wealth that has been owned by foundation cannot be transferred either directly or indirectly to the organs of the foundation, whether in the form of salary, wages or honorarium. Foundation Law gives an exception to the board of foundations to be able to earn salary from the foundation, but with the conditions set by the Foundation Law. This is because the board of the foundation has a great respon-
\end{abstract}


sibility regarding the stewardship of the foundation. On the basis of such responsibility, the foundation board is feasible salary. In practice, the fulfillment of a condition is only with the recognition only. These conditions are set forth in the articles of association, established by the founder, elder maker is not the founder and is not affiliated with the founders, elder makers and supervisors and the implementation of direct and has legal principles. Establishing budget is as the most important condition, so that other conditions have a legal basis. To guarantee the board is not affiliated with the founders, elder makers and supervisors, it is necessary to ask for proof of documents, for example the family card of each organ. If the articles of association not yet include the board, they may receive salary, and then the amendment of the articles of association shall be made.

\section{Keywords: foundation, foundation management, salary}

\section{LATAR BELAKANG}

Undang-Undang Yayasan telah menegaskan, bahwa yayasan adalah badan hukum yang terdiri atas kekayaan yang dipisahkan dan diperuntukkan untuk mencapai tujuan tertentu dibidang sosial, keagamaan, dan kemanusiaan, yang tidak mempunyai anggota. Salah satu upaya untuk mencegah agar yayasan tidak disalahgunakan, diadakanlah ketentuan Pasal 5 Undang-Undang Yayasan yang rumusannya sebagai berikut: "kekayaan yayasan baik berupa uang, barang maupun kekayaan lain yang diperoleh yayasan berdasarkan undang-undang ini, dilarang dialihkan atau dibagikan secara langsung atau tidak langsung, baik dalam bentuk gaji, upah maupun honorarium atau bentuk lain yang dapat dinilai dengan uang kepada pembina, pengurus dan pengawas".

Kekayaan yayasan tersebut berasal dari kekayaan yang dipisahkan, sumbangan atau bantuan, wakaf, hibah, hibah wasiat, atau diperoleh lain yang tidak bertentangan dengan Anggaran Dasar dan undang-undang. ${ }^{1}$ Badan hukum memiliki organ untuk menjalankan hak dan kewajibannya serta mengurus dan bertin-

\footnotetext{
${ }^{1}$ Pasal 26 Undang-Undang Yayasan.
}

dak mewakili yayasan. Berdasarkan Pasal 2 Undang-Undang Yayasan bahwa organ tersebut terdiri atas pembina, pengurus dan pengawas dengan fungsi dan wewenang serta tugas masing-masing. Untuk kepengurusan dalam kegiatan sehari-hari yayasan dilakukan oleh pengurus, dimana pengurus bertanggung jawab penuh dalam pengelolaan yayasan, ${ }^{2}$ sehingga yang diangkat menjadi pengurus bukanlah orang sembarangan tetapi harus mempunyai kemampuan yang baik dalam melakukan suatu perbuatan hukum berdasarkan kriteria yang telah ditentukan oleh udangundang dan mampu menjalankan kegiatan pengelolaan yayasan.

Disisi lain, pengurus yayasan juga mempunyai tanggung jawab lain sebagai makhluk budaya manusia yang mempunyai kebutuhan, dimana menurut Kierkegaard (1954), ${ }^{3}$ bahwa untuk menyempurnakan hidupnya manusia harus bekerja keras dan berkarya yang merupakan kebutuhan dan sekaligus bukti kualitas dan martabat manusia. Pada dasarnya kebutuhan manusia diklasifikasikan menjadi kebutuhan ekonomi, kebutuhan psikhis,

\footnotetext{
${ }^{2}$ Pasal 35 Undang-Undang Yayasan.

${ }^{3}$ Abdulkadir Muhammad, Etika Profesi Hukum, 1997, Bandung, Citra Aditya Bakti, h. 3.
} 
kebutuhan biologis, dan kebutuhan pekerjaan. ${ }^{4}$ Untuk memenuhi kebutuhan tersebut seseorang harus bekerja. Jika dihubungkan dengan pekerjaan seseorang sebagai pengurus pada yayasan, maka pekerjaan tersebut dapat digolongkan sebagai pekerjaan pada bidang tertentu dalam arti sempit ${ }^{5}$ dengan tujuan untuk memperoleh pendapatan.

Apabila ketentuan Pasal 5 UndangUndang Yayasan diterapkan, maka dikhawatirkan tidak akan ada yang bersedia menjadi pengurus yayasan secara cumacuma, sementara untuk jabatan pengurus akan sangat menyita waktu, ${ }^{6}$ sehingga Undang-Undang Yayasan pada Pasal 5 ayat (2) diadakan perkecualian, artinya tidak dilarang jika pengurus diberikan gaji, upah atau honorarium dalam hal pengurus yayasan bukan pendiri yayasan, tidak terafiliasi dengan pendiri, pembina dan pengawas serta melaksanakan kepengurusan yayasan secara langsung dan penuh. Perkecualian tersebut dapat dilakukan jika dimuat dalam Anggaran Dasar Yayasan ${ }^{7}$ yang digunakan sebagai acuan ${ }^{8}$ yang harus dipatuhi dalam perbuatan yang dilakukan pengurus dalam kegiatan kepengurusan yayasan.

Berdasar pada perkecualian tersebut, dalam arti bahwa pembina dan pengawas tetap dilarang untuk memperoleh gaji, upah atau honorarium meskipun terhadap tenaga, waktu dan pikirannya telah diberikan untuk kepentingan yayasan, sehingga karakteristik organ yayasan yang harus bekerja secara su-

\footnotetext{
${ }^{4}$ Ibid., h. 4.

${ }^{5}$ Ibid., h. 58.

${ }^{6}$ Rudhi Prasetya, Yayasan dam Teori dan Praktk, 2014, Jakarta, Sinar Grafika, h. 71.

${ }^{7}$ Pasal 5 ayat (2) Undang-Undang Yayasan.

${ }^{8}$ Ibid., h. 13.
}

karela ${ }^{9}$ demi kepentingan dan pencapaian tujuan yayasan sangat jelas terlihat kepada organ pembina dan pengawas.

Organ pengurus yayasan yang telah memperoleh keistimewaan dengan diberikannya ijin oleh undang-undang untuk memperoleh upah, gaji atau honorarium tentunya mempunyai tanggung jawab yang besar pula kepada yayasan yang diberikan oleh undang-undang kepada pengurus. Hal ini dibuktikan dengan adanya Pasal 31 ayat (1) menentukan bahwa pengurus adalah organ yayasan yang melaksanakan kepengurusan yayasan.

Kepengurusan yayasan dimaksud dalam pasal tersebut di atas, oleh UndangUndang Yayasan tidak mengatur secara tegas apa saja yang menjadi kewenangan pengurus, sehingga mengakibatkan terlihat bahwa kekuasaan pengurus sangatlah besar. Dalam penjelasan pasal tersebut juga hanya mengatakan "cukup jelas”, maka dapat dikatakan operasional yayasan semata-mata bergantung pada pengurus. Peran pengurus amat dominan dalam pengelolaan yayasan yang harus dijalankan semata-mata untuk mencapai maksud dan tujuan yayasan serta mempunyai kewenangan yang sangat penting terhadap pengelolaan atau jiwa yayasan itu sendiri.

Kepada pengurus yang tidak bermaksud baik, dengan sangat mudah dapat menggeser tujuan semula yayasan, menjadi suatu kegiatan usaha dengan tujuan mengejar keuntungan atau memperkaya diri, olehnya itu pada Pasal 35 UndangUndang Yayasan menyatakan secara tegas bahwa setiap pengurus dalam menjalankan tugasnya harus dengan itikad baik dan penuh tanggung jawab untuk kepentingan dan tujuan yayasan, sehingga untuk men-

${ }^{9}$ Penjelasan Umum Pasal 3 ayat (2) UndangUndang Yayasan. 
capai ketentuan tersebut dibutuhkan tolak ukur dari itikad baik pengurus yang dimuat dan dicantumkan dalam anggaran dasar sebagai syarat dalam hal pengurus dapat memperoleh upah, gaji atau honorarium yang ditetapkan oleh pembina ${ }^{10}$ sesuai dengan kemampuan kekayaan yayasan, agar pengurus dapat bekerja sesuai dengan maksud dan tujuan yayasan yang bukan untuk mencari keuntungan pada badan hukum yayasan.

Pengaturan mengenai syarat tersebut menjadi sangat penting dan menjadi patokan dalam hal pengurus yayasan melakukan perbuatan hukum pada yayasan. Selain itu juga sebagai syarat agar pengalihan harta kekayaan yayasan yang merupakan berpindahnya hak milik atas kepemilikan sebagian harta kekayaan tersebut kepada pengurus yayasan dalam bentuk gaji, upah atau honorarium mempunyai dasar hukum dan tujuannya tidak bertentangan dengan maksud dan tujuan yayasan.

Bentuk pengalihan harta kekayaan yayasan kepada pengurus sebagaimana dalam Undang-Undang Yayasan menyebutkan dalam bentuk gaji, upah atau honorarium, penulis dalam penyusunan karya ilmiah ini menggunakan istilah "gaji" yang diberikan kepada pengurus. Bahwasannya gaji merupakan sejumlah pembayaran kepada pegawai yang diberi tugas administratif dan manajemen yang biasanya ditetapkan secara bulanan. ${ }^{11} \mathrm{Da}-$ lam buku-buku manajemen sumber daya manusia istilah gaji digunakan untuk menggambarkan pembayaran jasa kerja untuk satuan waktu lebih panjang biasanya sebulan, jika dibandingkan dengan

\footnotetext{
${ }^{10}$ Pasal 5 ayat (3) Undang-Undang Yayasan.

${ }^{11}$ Sugiyarso dan Winarni, Dasar-Dasar Akuntansi Perkantoran, 2005, Yogyakarta, Media Pressindo, h. 95 .
}

upah yang digunakan untuk menggambarkan pembayaran jasa kerja untuk satuan waktu pendek misalnya per hari atau malahan per jam. ${ }^{12}$ Sedangkan istilah honorarium adalah merupakan bentuk penghargaan atas jasa kerja yang telah diberikan. Pengurus yayasan dalam hal ini, penulis mengkaji berdasarkan bentuk pengalihan kekayaan yayasan dalam bentuk gaji.

Olehnya itu, pemberian gaji kepada pengurus menjadi hal yang sensitif, sehingga pemberiannya harus mempunyai dasar hukum pengaturan agar kegiatan tersebut tidak bertentangan dengan maksud dan tujuan yayasan. Pengaturan tersebut dimuat dalam anggaran dasar sebagai seperangkat peraturan-peraturan yang diadakan pada waktu pendirian yayasan, yang dipakai sebagai acuan aturan permainan yang harus dipatuhi dalam gerak dan kegiatan yayasan. ${ }^{13}$ Menjadi sangat penting untuk diperhatikan, karena adanya ketentuan Pasal 70 Undang-Undang Yayasan yaitu dengan memberikan ancaman pidana paling lama 5 (lima) tahun, manakala dilanggarnya ketentuan Pasal 5 Undang-Undang Yayasan.

Di sisi lain, penggunaan syaratsyarat tersebut bukan hanya dituangkan dalam anggaran dasar, tetapi penerapan syarat tersebut sesuai dengan bukti yang ada untuk menetapkan syarat demikian, karena pengakuan secara lisan bisa saja diucapkan dengan tidak membuktikan dengan dokumen akan terpenuhinya syarat tersebut. Undang-Undang Yayasan tidak mengatur mengenai langkah yang dilakukan untuk pencapaian syarat pemberian gaji kepada pengurus yayasan,

\footnotetext{
${ }^{12}$ Www.landasanteori.com/2005/10/pengertian-gajidan-upah--definisi.html?m=1.

${ }^{13}$ Rudhi Prasetya, Yayasan dalam Teori dan Praktik, 2014, Jakarta, Sinar gRafika, h. 13.
} 
hanya sebatas menyebutkan syarat tersebut, dimana syarat tersebut juga perlu disertakan pembuktian agar tidak hanya sebagai pengakuan belaka dari organ yayasan. Serta memperhatikan hak pengurus bahwa setiap orang berhak untuk bekerja dan mendapat imbalan dan perlakuan yang adil dan layak dalam hubungan kerja. Dalam hal ini, bahwa pengurus mendapatkan gaji berdasar pada tanggung jawabnya yang besar dan tugas yang diberikan undang-undang untuk melakukan kepengurusn yayasan, sehingga hidup mati yayasan ada ditangan pengurus. Penetapan syarat pemberian gaji kepada pengurus yayasan bahwa pengurus bukan pendiri dan tidak terafiliasi dengan pendiri, pembina dan pengawas membatasi ruang haknya sebagai pengurus yayasan dalam melakukan kerja dan tidak sesuai dengan Pasal 28D Undang-Undang Dasar 1945.

Berdasarkan uraian latar belakang di atas, maka penulis memilih judul mengenai "Pemberian Gaji kepada Pengurus Yayasan Berdasarkan UndangUndang Yayasan" dengan rumusan masalah yaitu pengaturan mengenai syarat-syarat pemberian gaji kepada pengurus yayasan.

\section{PEMBAHASAN}

\section{SYARAT-SYARAT PEMBERIAN GAJI KEPADA PENGURUS YAYASAN BERDASARKAN UN- DANG-UNDANG YAYASAN}

Sebelum adanya Undang-Undang Yayasan, banyak terjadi pendiri merangkap sebagai pengurus ataupun sebaliknya. ${ }^{14}$ Hal ini dapat mengakibatkan timbulnya kepentingan pribadi dari pengurus yayasan yang tentu saja dapat merugikan yayasan dalam menjalankan kegiatannya. Dalam pasal 31 ayat (3) telah

${ }^{14}$ Penjelasan Umum Undang-Undang Yayasan. dijelaskan bahwa pengurus tidak boleh merangkap sebagai pembina atau pengawas. Sebaliknya juga dijelaskan di Pasal 29, larangan perangkapan jabatan dimaksud untuk meghindari kemungkinan tumpang tindih kewenangan, tugas dan tanggung jawab antara pembina, pengurus, dan pengawas yang dapat merugikan kepentingan yayasan atau pihak lain. Peran pengurus dalam Undang-Undang Yayasam diatur dalam Pasal 31 sampai dengan Pasal 39.

Berdasarkan tugas dan tanggung jawab yang dipikul oleh pengurus yayasan begitu besar, sehingga pengurus mendapatkan keistimewaan oleh undangundang, hal ini ditentukan pada Pasal 5 ayat (2) Undang-Undang Yayasa, bahwa pengurus dapat menerima gaji, upah atau honorarium dengan catatan bahwa pengurus yayasan tersebut bukan merupakan pendiri yayasan dan tidak terafiliasi dengan pendiri, pembina dan pengawas serta melaksanakan kepengurusan yayasan secara langsung dan penuh. Pengurus mempunyai tugas dan kewenangan melaksanakan kepengurusan dan perwakilan yang harus dijalankan semata-mata untuk mencapai maksud dan tujuan yayasan.

Pengecualian kepada pengurus dapat memperoleh gaji, upah atau honorarium dalam Pasal 5 Undang-Undang Yayasan sebagaimana pada ayat (2)nya, bahwa dapat ditentukan dalam anggaran dasar yayasan, serta pada ayat (3)nya menetukan, bahwa dengan ditetapkan oleh pembina yayasan sesuai dengan kemampuan yayasan. Ketentuan sebagaimana yang ditetapkan demikian menjadi wajib untuk dipenuhi dengan ditetapkan sebagai salah satu syarat dalam perkecualian tersebut, agar dapat sesuai dengan peraturan yang telah ditetapkan agar sesuai dengan maksud dan tujuan yayasan yang 
sebenanrnya yang diinginkan oleh undangundang serta mendapat kepastian dan perlindungan hukum.

Seseorang sebagai pengurus yayasan tentunya harus memenuhi syarat yang telah ditetapkan baik itu menurut undang-undang maupun menurut ketentuanketentuan yang telah ditetapkan oleh yayasan yang bersangkutan. ${ }^{15}$ Dalam praktek, terdapat yayasan yang menentukan syarat khusus ${ }^{16}$ yang harus dipenuhi untuk masuk sebagai bagian dari yayasan tersebut. Syarat tersebut dimuat dalam bentuk aturan khusus pada yayasan itu sendiri. Hal demikian dimaksudkan untuk mewujudkan fungsi dan tujuan yayasan sesuai dengan bidang kegiatan yayasan tersebut untuk meningkatkan dan menjamin keprofesionalismean pengurus sesuai dengan bidang dan kemampuan yang dimiliki. ${ }^{17}$ Syarat khusus yang ditetapkan oleh yayasan tersebut juga digunakan sebagai pedoman atau tolak ukur bagi pembina dalam pengangkatan pengurus yang sesuai dengan karakteristik yayasan itu sendiri yakni bergerak dalam bidang sosial, keagamaan atau kemanusiaan.

Syarat sebagai pengurus yang ditentukan oleh Undang-Undang Yayasan sebagaimana pada Pasal 35 ayat (2) yang menekankan adanya itikad baik pengurus dalam kepengurusan yayasan, bahwasannya setiap pengurus menjalankan tugas dengan itikad baik, dan penuh tanggung jawab untuk kepentingan dan tujuan yayasan. Ketentuan tersebut menunjukkan

\footnotetext{
${ }^{15}$ Misal peraturan khusus yang dibuat oleh yayasan itu sendiri.

${ }^{16}$ Peraturan Organisasi Nomor 3 Tahun 2015 tentang Pesantren Hidayatullah. Pesantren Hidayatullah adalah badan hukum sebagaimana berdasar pada akta pendirian Yayasan Pesantren Hidayatullah Kendari Nomor 02 tanggal 10 Oktober 2011.

${ }^{17}$ Berdasarkan keterangan dari Ketua pengurus salah satu yayasan di Kota Kendari.
}

bahwa diantara yayasan dan pengurus terdapat hubungan kepercayaan dalam menjalankan tugasnya. Hubungan kepercayaan (fiduciary relationship) antara yayasan dan pengurus ${ }^{18}$ merupakan hubungan dimana pengurus berkewajiban bertindak untuk kepentingan yayasan sebatas lingkup hubungan kepercayaan tersebut. Batasan ini dituangkan dalam Anggaran Dasar Yayasan dan diatur dalam Pasal 37 ayat (2) Undang-Undang Yayasan dan menjadikan tanggung jawab pengurus juga terbatas pada anggaran dasar tersebut.

Menurut Riana Susmayanti, ${ }^{19}$ pengurus menjalankan tugas dengan itikad baik bila sesuai dengan fiduciary duty, anggaran dasar dan Undang-Undang Yayasan, serta tidak bertentangan dengan ketertiban umum dan kesusilaan. Keberadaan Pengurus adalah demi pencapaian kepentingan dan tujuan yayasan, sehingga standar pengurus dalam membuat keputusan adalah untuk kepentingan yayasan dan keputusan dibuat untuk tujuan yang benar sesuai dengan maksud dan tujuan yayasan. ${ }^{20}$ Bila pengurus menguntungkan diri sendiri, pihak ketiga atau merugikan yayasan maka perbuatan itu memperlihatkan tidak adanya itikad baik dari pengurus tersebut.

\footnotetext{
${ }^{18}$ Anwar Borahima, Implikasi Yuridis Pemberlakuan Undang-Undang Nomor 16 Tahun 2001 tentang Yayasan (Disertasi), 2002, Program Pascasarjana Universitaslangga, h. 234.

${ }^{19}$ Dosen Fakultas Hukum Universitas Brawijaya Malang, dalam tulisannya yang dimuat di Jurnal Penelitian dan Pengembangan Hukum, Arena Hukum, Fakultas Hukum Universitas Brawijaya, Malang, Nomor 1, Tahun 1, Januari 2008. ISSN 20126-0235.

${ }^{20}$ Chatamarrasjid-1, Tujuan Sosial Yayasan dan Kegiatan Usaha Bertujuan Laba, Citra Aditya Bakti, Bandung, 2000, h. 96.
} 
Penjaminan adanya itikad baik tersebut, Undang-Undang Yayasan pada Pasal 49 yang mengatur bahwa pengurus membuat laporan tahunan secara tertulis yang memuat mengenai keadaan dan kegiatan serta hasil yang telah dicapai yayasan, juga laporan keuangan, laporan aktivitas, laporan arus kas dan catatan laporan keuangan. Kegiatan pengurus tersebut diawasi oleh pengawas yang merupakan organ yayasan yang bertugas melakukan pengawasan kepada pengurus dalam menjalankan kegiatan yayasan. Laporan tahunan tersebut dibuat dengan ketentuan, bahwa dalam pembuatan dokumen laporan tahunan ternyata tidak benar dan menyesatkan, maka pengurus dan pengawas secara tanggung renteng bertanggungjawab terhadap pihak yang dirugikan. $^{21}$

Berdasarkan kegiatan pengurus tersebut, sehingga ditetapkan ketentuan mengenai syarat-syarat yang harus dilakukan untuk dapat mempertanggung jawabkan pengecualian atau keistimewaan yang diberikan undang-undang kepada pengurus yayasan sebagai organ yang boleh menerima gaji, upah atau honorarium dari kekayaan yayasan. Agar sesuai dengan maksud dan tujuan yayasan bahwa kekayaan yayasan tidak boleh dialihkan atau dibagikan baik dalam bentuk gaji, upah, honorarium atau bentuk lain yang dapat dinilai dengan uang kepada pembina, pengurus atau pengawas, maka sebagai pengurus harus memenuhi syarat yang telah ditetapkan oleh undang-undang maupun syarat khusus yang ditetapkan yayasan itu sendiri, agar layak atau pantas menerima gaji, upah atau honorarium dengan tidak bertentangan dengan Undang-Undang Yayasan maupun peraturan

${ }^{21}$ Pasal 51 Undang-Undang Yayasan. lain yang dapat merugikan yayasan itu sendiri.

Syarat-syarat pemberian gaji, upah atau honorarium kepada pengurus yayasan, penulis mengkaji berdasarkan UndangUndang Yayasan yang dimuat dalam anggaran dasar yang telah dibakukan oleh Menteri Hukum dan Hak Asasi Manusia berdasarkan akta pendirian yayasan yang dibuat oleh Notaris. Syarat-syarat tersebut adalah sebagai berikut.

a. Harus dituangkan dalam anggaran dasar yayasan;

b. Ditetapkan oleh Pembina;

c. Sesuai dengan kemampuan yayasan;

d. Pengurus bukan pendiri dan tidak terafiliasi dengan pendiri, pembina dan pengawas; serta

e. Melaksanakan kepengurusan secara langsung dan penuh.

Syarat-syarat tersebut diatur pada berbagai pasal dalam Undang-Undang Yayasan, sebagai ketentuan (peraturan, petunjuk) yang harus diindahkan dan dilakukan. ${ }^{22}$

\section{Dituangkan dalam Anggaran Dasar Yayasan}

Ketentuan pemberian gaji kepada pengurus yayasan harus dituangkan dalam Anggaran Dasar Yayasan sebagaimana telah ditentukan pada Pasal 5 ayat (2) Undang-Undang Yayasan, karena anggaran dasar adalah seperengkat peraturanperaturan yang dibuat saat pendirian yayasan dan digunakan sebagai acuan aturan untuk melaksanakan kegiatan yayasan. $^{23}$ Dalam anggaran dasar inilah mengatur berbagai tugas dan wewenang dari pengurus termaksud bentuk berbagai kebijakan yang ditetapkan harus dipatuhi.

\footnotetext{
${ }^{22}$ Arti kata syarat menurut Kamus Besar Bahasa Indonesia (KBBI)

${ }^{23}$ Rudhy Prasetya, Yayasan dalam Teori dan Praktik, 2014, Jakarta, Sinar Grafika, h. 13.
} 
Anggaran dasar berlaku sebagai aturan dasar yayasan yang wajib dipatuhi oleh pembina, pengurus dan pengawas ${ }^{24}$ yang berlaku setelah akta pendirian yayasan disahkan oleh Menteri Hukum dan Hak Asasi Manusia. Dalam pembuatan anggaran dasar harus mengikuti persyaratan-persyaratan yang ditetapkan oleh Undang-Undang Yayasan dan memuat ketentuan-ketentuan pokok yang merupakan dasar bagi tata kehidupan yayasan, dimana hal-hal yang dimuat dalam anggaran dasar tersebut harus disusun secara ringkas, singkat dan jelas, agar dapat dimengerti oleh siapapun serta isi dan cara penyusunan anggaran dasar tidak boleh bertentangan dengan peraturan perundangan yang berlaku dan tidak bertentangan dengan ketertiban umum dan atau kesusilaan.

Anggaran dasar pada yayasan sama halnya pada perusahaan, bahwa langkah awal yang harus dilakukan untuk mendirikan perusahaan (misalnya pada Perseroan Terbatas) adalah menetapkan anggaran dasar perusahaan. Anggaran dasar tersebut selanjutnya akan dituangkan dalam akta pendirian Perseroan Terbatas (PT). ${ }^{25}$ Pada akta pendirian yayasan yang memuat anggaran dasar sebagai alat untuk mengatur kegiatan yayasan guna pencapaian maksud dan tujuan yayasan menjadi otentik, ${ }^{26} \mathrm{ka}-$ rena akta pendirian tersebut dibuat oleh pejabat umum yaitu Notaris.

\footnotetext{
${ }^{24}$ Gatot Supramono, Hukum Yayasan di Indonesia, 2008, Jakarta, Rineka Cipta, h. 48.

${ }^{25}$ Tuti Rastuti, Seluk Beluk Perusahaan dan Hukum Perusahaan, 2015, Bandung, Refika Aditama, h. 145.

${ }^{26}$ Menurut Kamus Besar Bahasa Indonesia, kata Otentik artinya dapat dipercaya, asli, tulen dan sah. Pasal 1868 KUHPerdata "suatu akta otentik adalah suatu akta yang dibuat dalam bentuk yang ditentukan undang-undang oleh atau di hadapan pejabat umum yang berwenang untuk itu.
}

Anggaran dasar dapat berguna untuk menjamin ketertiban kegiatan yayasan, karena dalam anggaran dasar tersebut memuat aturan tentang fungsi, tugas dan tata kerja dari organ yayasan, mencegah adanya kesewenang-wenangan dari organ yayasan, baik itu pembina, pengurus, pengawas maupun pelaksana kegiatan yayasan.

Pengurus yayasan yang bertanggungjawab penuh dalam menjalankan tugasnya dengan itikad baik sesuai dengan Pasal 16 ayat (4) Undang-Undang Yayasan dilakukan dengan mengindahkan peraturan perundang-undangan yang berlaku. Namun, menurut Rudhy Prasetya, ${ }^{27}$ bahwa tidak cukup hanya dengan mengindahkan peraturan perundang-undangan yang berlaku, melainkan mutlak harus pula mengindahkan seluruh ketentuan anggaran dasar. Jika sampai pengurus dalam menjalankan wewenangnya bertentangan dan atau tidak sesuai dengan ketentuan anggaran dasar, maka sebagai pengurus dapat dinyatakan telah melakukan ultra vires. Dalam kepustakaan dikatakan telah terjadi ultra vires, yaitu manakala ternyata pengurus dalam menjalankan perbuatan mewakili badan, pengurus telah melakukan perbuatan secara bertentangan atau tidak sesuai dengan anggaran dasar pada yang bersangkutan. $^{28}$

Pengurus yayasan dalam menjalankan tugasnya memiliki konsekuensi dari tugas dan tanggungjawab tersebut, maka apabila pengurus menjalankan tugasnya tidak sesuai dengan ketentuan anggaran dasar dan mengakibatkan kerugian yayasan atau pihak ketiga, Pasal 35 ayat (5) Undang-Undang Yayasan memberi sanksi, bahwa setiap pengurus bertanggung jawab

\footnotetext{
${ }^{27}$ Rudhi Prasetya, Yayasan dalam Teori dan Praktik, 2014, Jakarta, Sinar Grafika, h. 17. ${ }^{28}$ Ibid.
} 
secara pribadi. ${ }^{29}$ Olehnya itu, pemberian gaji, upah atau honorarium kepada pengurus harus dimuat dalam anggaran dasar sebagai bentuk penghargaan dalam mempertimbangkan tanggung jawab pengurus yang begitu besar untuk kepentingan yayasan yang berdasar pada Undang-Undang Yayasan, memberikan jaminan kepastian hukum bahwa pelaksanaan pemberian gaji, upah atau honorarium tersebut sesuai dengan prosedur dan kesepakatan diantara organ yayasan yang tidak bertentangan dengan Undang-Undang Yayasan maupun peraturan lain mengenai maksud dan tujuan yayasan.

Pentingnya pemberian gaji, upah atau honorarium bagi pengurus harus dituangkan dalam Anggaran Dasar Yayasan adalah agar penggunaan kekayaan yayasan tidak disalahgunakan oleh organ yayasan dan berlandaskan pada maksud dan tujuan yayasan yang sebenarnya yaitu bukan untuk mencari keuntungan. Gaji, upah atau honorarium tersebut dimaksudkan sebagai bentuk penghargaan kepada pengurus yayasan yang mempunyai tugas sangat besar dalam kegiatan pengelolaan yayasan, yang pastinya dengan syarat yang telah ditentukan baik menurut undang-undang maupun peraturan lain.

\section{Ditetapkan oleh Pembina}

Pemberian gaji kepada pengurus yayasan ditetapkan oleh pembina, sesuai dengan ketentuan Pasal 5 ayat (3) UndangUndang Yayasan. Berdasarkan wewenang pembina yang dituangkan dalam Pasal 28 ayat (2) Undang-Undang Yayasan, yaitu:

a. keputusan mengenai perubahan anggaran dasar;

b. pengangkatan dan pemberhentian anggota pengurus dan anggota pengawas;

${ }^{29}$ Ibid., h. 94. c. penetapan kebijakan umum yayasan berdasarkan Anggaran Dasar Yayasan;

d. pengesahan program kerja dan rancangan anggaran tahunan yayasan; dan

e. penetapan keputusan mengenai penggabungan atau pembubaran yayasan.

Kelima kewenangan tersebut di atas dilakukan dengan cara melalui rapat anggota pembina, karena pembina merupakan lembaga yang tidak mungkin setiap anggotanya dapat melakukan sendiri-sendiri. $^{30}$

Undang-Undang Yayasan menghendaki lebih dari satu orang pembina, sehingga yang menentukan suatu keputusan adalah Rapat Pembina. Istilah pembina dimaksudkan agar alat perlengkapan tersebut akan benar-benar melakukan pembinaan atau memberikan keputusan-keputusan atau kebijakankebijakan yang dapat memajukan maupun mengembangkan yayasan. ${ }^{31}$ Anggota pembina diangkat dari orang perseorangan yang merupakan pendiri yayasan dan atau mereka yang berdasarkan rapat anggota pembina dinilai mempunyai dedikasi tinggi $^{32}$ untuk mencapai maksud dan tujuan yayasan. Para anggota pembina bekerja secara sukarela tanpa menerima atau diberi gaji, honor, upah atau tunjangan tetap.

Bila memperhatikan kewenangankewenangan yang dimiliki oleh pembina yayasan, dapat disimpulkan bahwa pembina yang sebelumnya sebagai pendiri yayasan merupakan organ yayasan yang

\footnotetext{
${ }^{30}$ Gatot Supramono, Hukum Yayasan di Indonesia, 2008, Jakarta, Rineka Cipta, h. 80.

${ }^{31}$ Gatot Supramono, Hukum Yayasan di Indonesia, 2008, Jakarta, Rineka Cipta, h. 75.

${ }^{32}$ Pasal 27 ayat (3) Undang-Undang Yayasan.
} 
memegang kekuasaan tertinggi dalam yayasan, yang tugas utamanya memonitoring usaha pencapaian maksud dan tujuan yayasan. Untuk menghindari tumpang tindih kewenangan, tugas dan tanggung jawab yang dapat merugikan kepentingan yayasan atau pihak lain, anggota pembina tidak boleh merangkap sebagai anggota pengurus, anggota pengawas dan atau pelaksana kegiatan. Apabila yayasan tidak lagi mempunyai pembina maka paling lambat 30 hari harus diadakan rapat gabungan anggota pengurus dan anggota pengawas untuk mengangkat pembina. ${ }^{33}$

Dengan kewenangan tersebut, diketahui bahwa pembina hanya dapat bertindak secara ke dalam, sesuai dengan kewenangan tersebut, terutama hal-hal yang bersifat kebijakan umum yang mendasari kegiatan yayasan dan yang harus dilaksanakan oleh pengurus dalam menjalankan kepengurusan yayasan. Pembina tidak dapat bertindak keluar atas nama yayasan. ${ }^{34}$ Selain wewenang, pembina memiliki tugas sebagaimana diatur dalam Pasal 30 ayat (1) UndangUndang Yayasan, mengenai rapat anggota pembina yang ditetapkan sekurangkurangnya sekali dalam satu tahun. Dalam rapat tahunan tugas pembina juga telah ditetapkan oleh Pasal 30 ayat (1), yaitu melakukan evaluasi tentang kekayaan, hak dan kewajiban yayasan.

Kewenangan pembina dalam menetapkan anggaran dasar mengenai kekayaan yayasan dilakukan dengan melakukan evaluasi mengenai kekayaan yayasan, pembina dapat melihat dalam laporan tahunan, karena di dalam laporan

\footnotetext{
${ }^{33}$ Pasal 27 ayat (4) Undang-Undang Yayasan.

${ }^{34}$ Murjiyanto. Badan Hukum Yayasan (Aspek Pendirian dan Tanggung Jawab), 2011, Yogyakarta, Liberty, h. 30.
}

tersebut akan tampak bagaimana keadaan dan kegiatan yayasan selama tahun buku yang lalu serta hasil yang dicapai. Kemudian tentang hak dan kewajiban yayasan tahun lampau, pembina dapat melihat dari catatan yang wajib dibuat oleh pengurus berdasarkan Pasal 48 ayat (1), di mana pengurus membuat dan menyimpan catatan yang berisi keterangan tentang hak dan kewajiban serta hal lain yang berkaitan dengan kegiatan usaha yayasan. Olehnya itu, penetapan pemberian gaji setiap bulan hanya dilakukan oleh pembina karena berdasarkan kewenangan yang dimiliki oleh pembina yang diberikan oleh undang-undang sebagai organ yang menetapkan kebijakan pada yayasan yang berdasarkan Anggaran Dasar Yayasan. Dalam artian bahwa kegiatan yang berhubungan dengan penggunaan kekayaan yayasan harus dengan penetapan pembina. Selain itu, penetapan tersebut juga merupakan kewenangan pembina yang tidak diserahkan kepada pengurus atau pengawas sebagaimana ketentuan Pasal 28 ayat (1) Undang-Undang Yayasan. Penetapan pembina dilakukan dalam bentuk Surat Keputusan Pembina, baik itu dinotarilkan atau hanya disahkan saja pada rapat pembina dan disetujui oleh seluruh anggota yayasan (organ).

\section{Sesuai dengan Kemampuan Yayasan}

Dalam sejarahnya diketahui bahwa yayasan merupakan suatu himpunan harta kekayaan yang disisihkan oleh para pendirinya untuk kegiatan sosial dan segisegi ideal lainnya. ${ }^{35}$ Setelah berlakunya Undang-Undang Yayasan, maka ditegaskan kembali melalui beberapa pasalnya, yang menggambarkan bahwa yayasan tidak dimaksudkan untuk tujuan komersial. Di dalam Undang-Undang Yayasan, bah-

${ }^{35}$ Ibid., h. 67. 
wa yayasan sebagai badan hukum non komersial, dapat dilihat dari beberapa ketentuan, yaitu pada Pasal 1 ayat (1) mengenai pengertian yayasan yaitu tentang harta kekayaan yang dipisahkan, mengandung arti bahwa kekayaan yang telah dipisahkan tersebut sudah terpisah secara keperdataan dengan pendirinya yang memisahkan kekayaannya, sehingga kekayaan tersebut sebagai kekayaan yayasan yang digunakan untuk mencapai maksud dan tujuan yayasan. Tujuan yayasan yang menyangkut bidang sosial, keagamaan dan kemanusiaan nampak jelas menggambarkan bahwa yayasan tidak dimaksudkan untuk tujuan komersial. Dalam yayasan tidak terdapat anggota, sesuai dengan pengertian bahwa pada prinsipnya yayasan adalah sebuah harta kekayaan yang dipisahkan, sehingga yayasan sebenarnya tidak ada pemiliknya. ${ }^{36}$ Jika terdengar kata anggota dalam yayasan, hal ini dimaksudkan anggota badan pengurus dari yayasan itu. $^{37}$

Orang yang melakukan kegiatan dalam yayasan tidak dimaksudkan untuk mencari keuntungan untuk kemudian dibagi seperti halnya pada perusahaan. Bahkan kalau yayasan bubar, maka sisa kekayaannya tidak boleh dibagikan kepada siapapun termaksud kepada pembina, pengurus dan pengawas. Dengan demikian, pada dasarnya semua kekayaan yayasan harus dipergunakan untuk mencapai maksud dan tujuan yayasan. Namun yayasan juga wajib membayar segala biaya atau ongkos yang dikeluarkan oleh organ yayasan dalam rangka menjalankan tugas yayasan. $^{38}$ Ketentuan ini kiranya dapat digunakan sebagai dasar dan dapat dimak-

\footnotetext{
${ }^{36}$ Ibid., h. 68.

${ }^{37}$ Komar Andasasmita, Notariat II, 1983, Bandung, Sumur, h. 992.

${ }^{38}$ Pasal 6 Undang-Undang Yayasan.
}

nai, bahwa sekalipun terdapat adanya larangan pembagian keuntungan baik langsung ataupun tidak langsung kepada organ yayasan dalam bentuk apapun termaksud gaji, upah atau honorarium, namun yayasan tetap wajib membiayai biaya atau ongkos yang harus dikeluarkan oleh organ yayasan dalam rangka menjalankan tugas yayasan.

Pemberian gaji kepada pengurus yayasan berdasarkan Undang-Undang Yayasan, disesuaikan dengan kemampuan yayasan, sebagimana telah ditentukan oleh Pasal 5 ayat (3), bahwa pengurus dapat menerima gaji, upah atau honorarium dilakukan sesuai dengan kemampuan yayasan. Hal tersebut dikarenakan selain kekayaan yang berasal dari pemisahan kekayaan pendiri, serta sumber perolehan kekayaan lain sebagaimana ditentukan pada Pasal 26 ayat (2) Undang-Undang Yayasan yaitu berasal dari sumbangan atau bantuan yang tidak mengikat, wakaf, hibah, hibah wasiat dan perolehan lain yang tidak bertentangan dengan anggaran dasar yayasan maupun peraturan perundangundangan yang berlaku. Perolehan kekayaan tersebut tidak menjamin bahwa akan terus menerus atau berkelanjutan sebagai pemasukan bagi kekayaan yayasan.

Olehnya itu, pemberian gaji kepada pengurus yayasan yang dalam tugasnya sangat menyita waktu dan bertanggung jawab penuh pada yayasan, tidak salah jika diberikan pengecualian, dengan dasar bahwa segala kebutuhan untuk kepentingan yayasan dapat terpenuhi guna untuk mencapai maksud dan tujuan yayasan. Berbagai pertimbangan mengenai kemampuan yayasan terutama kemampuan ekonomi yayasan dapat mempengaruhi pemberian gaji, upah atau honorarium kepada pengurus yayasan. Sebagai contoh, suatu yayasan dalam memberikan gaji 
kepada pengurusnya tidak segan-segan berani menawarkan gaji yang tinggi bagi seorang pengurus yang profesional, karena memang kemampuan keuangannya telah mapan sehingga berani menawarkan gaji yang besar. Sebaliknya, yayasan yang masih memiliki kemampuan keuangan kurang yang menyebabkan pemberian gaji, upah atau honorarium kepada pengurus yayasan rendah, hal demikian tidak menjadi suatu permasalahan, karena pada dasarnya tujuan utama yayasan adalah menjalankan kegiatan yayasan dibidang sosial, keagamaan dan kemanusiaan, sehingga pengurus yayasan tidak boleh mencari keuntungan pada yayasan dan sebagaimana patokan pengaturan yang dituangkan dalam anggaran dasar tidak menentukan nilai dari gaji, upah atau honorarium tersebut kepada pengurus yayasan. Penyesuaian kemampuan yayasan ini dilakukan oleh pembina yang mempunyai kewenangan akan penetapan penggunaan kekayaan yayasan dalam anggaran dasar. Pembina dalam melakukan penetapan pemberian gaji kepada pengurus yayasan dengan memperhatikan kekayaan yayasan. Karena meskipun anggaran dasar telah menyebutkan bahwa pengurus dapat digaji, tetapi jika kekayaan yayasan tidak mencukupi akan hal tersebut, dimana yang harus diutamakan adalah pencapaian maksud dan tujuan yayasan maka penetapan pemberian gaji tersebut tidak dapat dilakukan. Untuk mengukur mengenai kemampuan yayasan dengan berdasar pada hasil evaluasi kekayaan yayasan dari laporanlaporan yang telah dibuat oleh pengurus yayasan sesuai dengan kegiatan sesuai maksud dan tujuan yayasan. Dimana telah diketahui bahwa yang mempunyai kewenangan dalam pembuatan laporan tersebut terhadap pengelolaan yayasan adalah pengurus sebagai bentuk pertanggung jawabannya terhadap pembina.

\section{Pengurus Bukan Pendiri dan Tidak Te- rafiliasi dengan Pendiri, Pembina dan Pengawas}

Undang-Undang Yayasan tidak banyak menetapkan mengenai persyaratan seseorang untuk menjadi pengurus yayasan. Undang-undang memberikan ketentuan pada Pasal 31 ayat (2) menetapkan, bahwa yang dapat diangkat menjadi pengurus adalah orang perseorangan yang mampu melakukan perbuatan hukum. Dari ketentuan tersebut, sehingga memungkinkan pendiri yang bukan sebagai pembina dapat menjadi pengurus yayasan tersebut. Dalam hal mengenai pemberian gaji, upah atau honorarium kepada pengurus yayasan, rupanya pada Pasal 5 ayat (2) menentukan bahwa pengurus bukan pendiri, sehingga dapat disimpulkan bahwa jika pendiri sebagai pengurus yayasan maka tetap tidak boleh memperoleh gaji, upah atau honorarium.

Pemberian gaji, upah atau honorarium kepada pengurus yayasan hanya dapat dilakukan kepada seorang pengurus yang tidak terafiliasi dengan pendiri, pembina, dan pengawas. $^{39}$ Maksud dari terafiliasi adalah hubungan keluarga karena perkawinan atau keturunan sampai derajat ketiga, baik secara horizontal, maupun vertikal. $^{40}$ Ketentuan demikian untuk menghindari terjadinya praktek-praktek penyalahgunaan fungsi yayasan oleh organ yayasan, bahwa yayasan merupakan badan hukum yang mempunyai tujuan sosial, kemanusiaan dan keagamaan dan tidak mengejar keuntungan. Kekayaan yayasan tidak boleh dibagi-bagi kepada siapapun.

\footnotetext{
${ }^{39}$ Pasal 5 ayat (2) huruf a Undang-Undang Yayasan.

${ }^{40}$ Penjelasan Pasal 5 ayat (2) huruf a UndangUndang Yayasan.
} 
Jadi, mutlak milik yayasan, karena yayasan badan hukum, dan untuk menghindari praktek yang selama ini (sebelum adanya hukum positif mengenai yayasan), maka segala wewenang organ dalam kegiatan pengelolaan yaaysan diberikan pembatasan oleh undang-undang dan penggunaan kekayaan yayasan harus sesuai dengan yang ditetapkan UndangUndang Yayasan yang bertujuan agar kegiatan yayasan sesuai dengan maksud dan tujuannya yang bersifat non komersial. Selain itu, Menurut Chatam Rasjid, ${ }^{41}$ untuk pengurus sebaiknya dilihat terlebih dahulu kondisi orang tersebut, apakah layak digaji atau tidak. Apalagi mengingat kondisi ekonomi pengurus yayasan di Indonesia yang masih kurang bagus. Termaksud hubungannya dengan pendiri atau pembina dan pengawas, pengurus tidak boleh terafiliasi dengan pendiri atau pembina dan pengawas serta tidak boleh mendapatkan gaji, upah atau honorarium karena untuk mengantisipasi akalakalan dari organ tersebut yang mengakibatkan tujuan sosial, keagamaan atau kemanusiaannya hilang.

Mengenai syarat yang satu ini, dimana pengurus bukan pendiri dan tidak terafiliasi dengan pembina dan pengawas menjadi tantangan tersendiri, karena untuk memastikan hubungan pengurus dengan pendiri, pembina atau pengawas juga butuh proses. Di sisi lain, syarat ini sangat diperlukan untuk mengantisipasi penggunaan kekayaan yayasan agar tidak salah sasaran dan diperuntukkan untuk tujuan yang jelas dalam hal penggunaannya. Peran Notaris sebagai pembuat Akta Pendirian Yayasan dalam pembuatannya, terlebih dahulu menanyakan keinginan

\footnotetext{
${ }^{41}$ http://www.hukumonline.com/berita/baca/hol330 8/karyawan-yayasan-boleh-digaji (diakses tanggal 11 Agustus 2017)
}

dari para penghadap apakah pengurus yayasan akan mendapatkan gaji dari yayasan. Jika para penghadap mengatakan iya, maka Notaris perlu memperhatikan syarat-syarat pemberian gaji kepada pengurus sesuai Undang-Undang Yayasan dan peraturan lain yang dianggap perlu. Untuk itu, untuk memenuhi syarat bahwa pengurus bukan pendiri dan tidak terafiliasi dengan pendiri, pembina dan pengawas perlu diadakan pembuktian berupa pernyertaan dokumen yang dapat membuktikan demikian. Misalkan, kartu keluarga masing-masing organ yayasan dan bukti lain yang dianggap perlu.

\section{Melaksanakan Kepengurusan Secara Langsung dan Penuh}

Setelah Undang-Undang Yayasan lahir, posisi dan batas wilayah kerja pengurus menjadi tegas. Pengurus diadakan oleh Undang-Undang Yayasan dengan tugas khusus sebagai pelaksana. Dengan tugas itu, pengurus tidak boleh orang yang terafiliasi $^{42}$ dengan pendiri atau pembina dan pengawas. Mereka diangkat oleh pembina berdasarkan kapabilitas yang dimiliki serta berkemampuan melakukan perbuatan hukum. Atas dasar itu, mereka diberi kepercayaan untuk melaksanakan kepengurusan yayasan. Ini tidak setengahsetengah, tapi kepengurusan penuh.

Hal itu sudah ditegaskan dalam pasal 35 ayat (1) dan ayat (5) serta Penjelasan Undang-Undang Yayasan. Dalam ketentuan itu ditekankan, bahwa pengelolaan yayasan dilakukan sepenuhnya oleh pegurus. Penguruslah yang bertanggung jawab penuh mengelola kekayaan dan pelaksanaan kegiatan yayasan. Pengurus

\footnotetext{
${ }^{42}$ Istilah terafiliasi menurut Penjelasan Pasal 5 ayat (2) huruf a Undang-Undang Yayasan adalah hubungan keluarga karena perkawinan atau keturunan sampai derajat ketiga, baik secara horizontal maupun vertikal.
} 
pula yang diberi hak untuk mewakili yayasan, baik di dalam maupun di luar pengadilan.

Penegasan-penegasan

terse-

but mengandung banyak implikasi. Di antaranya ialah pertama, kegiatan pengelolaan yayasan dengan berbagai kegiatannya adalah urusan pengurus. Kedua, kegiatan apa pun yang sifatnya implementasi kebijakan pembina adalah urusan pengurus. Pembina dan/atau Pengawas tidak boleh ikut campur, kecuali ada penyimpangan atau pelanggaran. Itupun harus dilakukan secara prosedural. Sebab jika hal itu dilakukan, maka pembina dan/atau pengawas yang demikian identik dengan tindakan memasuki halaman rumah orang dengan lompat pagar. Dampak dari tindakan itu bisa dibayangkan. Selain pengelolaan organisasi yayasan kacau, potensi konflik, bahkan konflik benaran, berpeluang besar terjadi.

Untuk itu, pengurus yayasan tidak boleh sembarangan. Syarat utamanya adalah memiliki itikad baik. Undang-Undang Yayasan mengharuskan demikian. Atas dasar itu, dengan penuh tanggung jawab ia melaksanakan kepengurusan yayasan. Jika tidak, maka resiko kelalaian dan kesalahan sekecil apa pun tidak akan ditanggungkan kepada yayasan. Tapi pada diri pengurus sendiri. Ini nampak dalam ketentuan Pasal 35 ayat (5), bahwa "Setiap pengurus bertanggung jawab penuh secara pribadi apabila yang bersangkutan dalam melaksanakan tugasnya tidak sesuai dengan ketentuan Anggaran Dasar, yang mengakibatkan kerugian yayasan atau pihak ketiga."

Dalam menjalankan tugas dan wewenang tersebut, yang dimaksud dengan secara langsung dan penuh adalah melaksanakan tugas kepengurusan sesuai dengan ketentuan hari dan jam kerja yayasan bukan bekerja paruh waktu (part time). Pemberian gaji kepada pengurus yayasan dilakukan jika tugas/wewenang dan tanggung jawab daripada pengurus yayasan telah dilakukan sesuai dengan Undang-Undang Yayasan dan Anggaran Dasar Yayasan yang tidak merugikan yayasan dan bersungguh-sungguh dalam menjalankannya.

\section{KESIMPULAN}

Syarat-syarat pemberian gaji, upah, honorarium kepada pengurus yayasan berdasarkan Undang-Undang Yayasan yaitu pertama, harus dituangkan dalam anggaran dasar yayasan, karena anggaran dasar digunakan sebagai acuan atau dasar untuk menjalankan segala ketentuan dan kegiatan pada yayasan. Kedua, ditetapkan oleh pembina, karena pembina mempunyai kewenangan dalam hal penetapan Anggaran Dasar Yayasan. Ketiga, sesuai dengan kemampuan yayasan, karena tujuan yayasan yaitu bukan untuk mencari keuntungan, sehingga pemberian gaji, upah atau honorarium dilakukan setalah kebutuhan yayasan terpenuhi dan masih memiliki kekayaan yang cukup. Keempat, pengurus bukan pendiri dan tidak terafiliasi dengan pendiri, pembina dan pengawas, karena untuk menghindari penyalahgunaan kegiatan yayasan yang tidak bertujuan sosial, kemanusiaan dan keagamaan. Kelima, melaksanakan kepengurusan secara langsung dan penuh, untuk menjamin bahwa pengurus yayasan melakukan kepengurusan yayasan dengan itikad baik dan bertanggung jawab penuh. Setiap syarat mempunyai hubungan satu sama lain. Penetapan dalam anggaran dasar yayasan perlu mendapat perhatian dari Notaris, jika yayasan tersebut menginginkan pengurusnya boleh memperoleh gaji. Agar syarat lain yang dituangkan dalam anggaran dasar 
mempunyai bukti yang kuat bahwa syarat tersebut benar dimiliki oleh pengurus yayasan. Untuk memastikan bahwa pengurus tidak terafiliasi dengan pendiri, pembina dan pengawas maka perlu dimintakan pembuktian berupa dokumendokumen, misalkan kartu keluarga masingmasing organ. Dasar utama dalam kegiatan pengelolaan yayasan adalah berdasar kepada Anggaran Dasar Yayasan, apabila anggaran dasar belum mencantumkan demikian, dilakukanlah perubahan anggaran dasar.

\section{DAFTAR PUSTAKA}

Andasasmita, Komar., Notariat II, Sumur, Bandung, 1983.

Chatamarrasjid-1, Tujuan Sosial Yayasan dan Kegiatan Usaha Bertujuan Laba, Citra Aditya Bakti, Bandung, 2000

Muhammad, Abdulkadir., Etika Profesi Hukum, Citra Aditya Bakti, Bandung, 1997.

Murjiyanto, Badan Hukum Yayasan, Liberty, Yogyakarta, 2011.

Prasetya, Rudhi., Yayasan dalam Teori dan Praktik, Sinar Grafika, Jakarta, 2014.

Rastuti, Tuti., Seluk Beluk Perusahaan dan Hukum Perusahaan, Refika Aditama, Bandung, 2015.

Sugiyarso dan Winarni, Dasar-Dasar Akuntansi Perkantoran, Media Pressindo, Yogyakarta, 2005

Supramono, Gatot., Hukum Yayasan di Indonesia, Rineka Cipta, Jakarta, 2008.

\section{Karya Ilmiah :}

Borahima, Anwar., Implikasi Yuridis Pemberlakuan Undang-Undang Nomor 16 Tahun 2001 Tentang Yayasan,
(Disertasi), Program Pascasarjana

Universitas Airlangga. 2002.

Peraturan Perundang-undangan :

Undang-Undang Nomor 16 Tahun 2001

Tentang Yayasan.

Undang-Undang Nomor 28 Tahun 2004 Tentang Perubahan atas UndangUndang Nomor 16 Tahun 2001

Tentang Yayasan.

\section{Webpage :}

http://www.hukumonline.com/berita/baca/ hol3308/karyawan-yayasan-boleh-digaji 